dying of coeliac disease and Addison's disease showed lymphocytes, mononuclear cells, and giant cells in her fibrotic adrenal glands; it is likely that she had sarcoidosis initially because she had earlier shown generalised lymphadenopathy and erythema nodosum." Five patients with sarcoidosis had adrenal failure, ${ }^{6}$ and it is interesting that coeliac disease is also occasionally associated with active tuberculosis.

Chronic changes only were seen in the lung biopsy in the case described by $\mathrm{Dr} J$ Cummiskey and his colleagues (5 June, $p$ 1401), and the immune response had faded after four years. But the pulmonary inflammation was still active in other reported cases. Three patients whose lungs were biopsied showed non-caseating granulomas. One of them, biopsied percutaneously by $\mathrm{Mr} \mathrm{M}$ MeredithBrown, had a positive Mantoux test, a calcified ring-shadow in the same lung, and bilateral apical scars. She also showed the cell-mediated immunity which is found in sarcoidosis, Crohn's disease, and BCG non-reactors. "The syndrome may have therefore been caused by sarcoidosis in these three cases, and in one other. ${ }^{9}$ The sarcoid agent may be a cause of "extrinsic alveolitis," but earlier and wider investigation of such cases is needed to prove this point.

Gerald A MACGREgor

St Luke's Hospital

Guildford, Surrey

Karlish, A J, Lancet, 1971, 1, 1077.

Gone, E, Myren, J, and Refsum, S B, Acta Patho

65, 24.
Hindle, $W$, and Creamer, B, British Medical fournal, 1965, 2, 455.

Karlish, A J, Lancet, 1972, 1, 438

Clinicopathological Conference, British Medical fournal, 1970, 2, 711. Mournal, 1970, 2, Proceedings of the Royal Society of
Medicine, G A $1974,67,221$.

Barry, E R, Norris, J S, and Read, A E A, Gut, 1970, $11,743$.

"MacGregor, G A, Lancet, 1971, 2, 1431.
MacGregor, G A, British Medical fournal, 1971, 1, 51.

\section{Vaginal candidosis}

SIR, - We are disturbed by statements about antifungal agents made in your leading article on vaginal candidosis (14 February, p 357) and subsequent comment. We agree that, in general, antibiotics used for systemic infections should be avoided in topical treatment; but in the case of amphotericin we support Dr G R Daniel's contention (19 June, p 1528) that the emergence of resistant candida clones during treatment is so rare that this need hardly be considered when amphotericin $\mathrm{B}$ is clinically desirable. In your editorial reply (19 June, p 1529) you were able to cite only one documented case ${ }^{1}$ to which may be added one further convincing instance-of emergence of resistant Candida tropicalis during amphotericin B treatment of candida pyelonephritis." Both occurred in systemic infections for which nystatin is not used, and comparison of the two drugs cannot be made. On the other hand resistance to both nystatin and amphotericin $B$ can be produced with difficulty in vitro and there is some cross-resistance." The choice between the two agents may not be significant in the treatment of vaginal candida infection, and evidence already cited suggests that nystatin may be the better. ${ }^{4}$ In ora candida infection, however, amphotericin B is greatly preferable for its palatability and stability in aqueous suspension." Much more evidence is required of the occurrence of resistance during treatment and the distinction between amphotericin B and nystatin in this respect before we should deny the topical use of amphotericin B.

In contrast, flucytosine (5-fluorocytosine) is well known for primary resistance in yeast isolates ${ }^{i}$ and for emergence of resistance during treatment of conditions such as urinary tract infection.' While we were interested in the report from Drs $R$ Pumpianski and $S$ Ganor (June 19, p 1529) of its effectiveness in vaginal candida infection, we should expect the emergence of mutants indifferent to flucytosine and for this reason we should not recommend this treatment. Perhaps it is flucytosine and not amphotericin which should be reserved for use in systemic infections. ${ }^{*}$

D C E SPELLER

Department of Microbiology,

Bristol Royal Infirmary

Drouhet, E, Modern Treatment, 1970, 7, 539.

Drutz, D J, and Woods, R A, Clinical Research, 1973, 21, 270

thar, M A, and Winner, H I, fournal of Medical Microbiology, 1971, 4, 505. conka, G W, British fournal of Venereal Diseases, 1967, 43, 210

Ewing, A, Practitioner, 1967, 199, 62.

peller, D C E, and Davies, M G, Fournal of Medical Microbiology, 1973, 6, 315 .

' Holt, R J, Infection, 1974, 2, 95.
" Holt, R J, British Medical Journal, 1974, 3, 523.

\section{Treatment of Volkmann's ischaemic} contracture

SIR,-May I comment briefly on your leading article "New muscles for old" (24 April, p 976) ?

In the idea of removing the infarct-the essential lesion in Volkmann's ischaemia-we found ourselves 20 years behind Tavernier and his colleagues in Lyon; ignorance which was humbly acknowledged later. ${ }^{1}$ That was unfortunate but not important. What really matters is that you write that I "pointed out the advantage of removing the infarct within a few weeks of its occurrence and thereby diminishing the amount of scarring and its effects on nearby nerves and muscle." What I wrote in italics was: "It is wrong to carry out this radical treatment within three months from the time of injury and it is probably wiser to wait six months." The reason is that, depending on the severity of the initial ischaemia, useful spontaneous recovery is possible in some of the affected muscles and rather more in affected nerves. The clinical and pathological evidence for this policy of delay was, I think, adequately presented.

H J SEDDON

Stanmore, Middx

Seddon, H J, British Medical fournal, 1964, 1, 1587 Seddon, $\mathrm{H}$ J, fournal of Bone and foint Surgery, 1956

\section{Aetiology of anencephaly and spina} bifida

SIR,-We read with interest the discussion by Sir Cyril Clark and others (27 December $1975 \mathrm{p} \mathrm{743)}$ of the hypothesis that residua pathological trophoblastic material from either a previous miscarriage or a co-twin may interact unfavourably with another fetus to produce anencephaly spina bifida or both (ASB)

In our series of 1575 cases the following factors are consistent with the hypothesis: lack of concordance for neural tube defect (NTD) in twins (4 in 35 pairs), high incidence of females (934:641), an observed maternal age effect, and greater prevalence in lower social classes. There was a decline both in the rate of twinning and in the rate for anencephaly over the last 20 years. There was no discrepancy in the sex of children born before or after an affected case.

Two further points to support the theory are the greater risks of recurrence in consecutive pregnancies, within 12 to 18 months of one another, and that we have recorded a woman whose reproductive history was: (1) female, spina bifida ; (2) female, anencephalic ; (3) male, normal; (4) hydatidiform mole; (5) male, spina bifida; (6) male, normal.

We examined the detailed obstetric histories of 100 patients seen consecutively for genetic counselling after the birth of an affected child (21 anencephalic, 79 meningomyelocele), including seven mothers with two consecutive affected children and one (described above) with three affected children and a hydatidiform mole (109 cases). The results of the pregnancies immediately before and immediately after the birth of each affected child are shown in the table.

\begin{tabular}{|c|c|c|}
\hline \multirow{2}{*}{$\frac{\text { Immediately before }}{\begin{array}{c}\text { First born ; no history } 37 \\
\text { of miscarriage }\end{array}}$} & \multicolumn{2}{|c|}{ Immediately after } \\
\hline & $\begin{array}{l}\text { No further } \\
\text { pregnancies }\end{array}$ & 31 \\
\hline $\begin{array}{ll}\text { Previous child normal } & 34 \\
\text { Spontaneous } & 23\end{array}$ & Normal child & $\begin{array}{r}59 \\
8\end{array}$ \\
\hline $\begin{array}{l}\text { abortion } \\
\text { Induced abortion }\end{array}$ & $\begin{array}{l}\text { abortion } \\
\text { Induced abortion }\end{array}$ & 1 \\
\hline $\begin{array}{l}\text { Stillbirth or } \\
\text { neonatal death }\end{array}$ & Stillbirth & 2 \\
\hline $\begin{array}{l}\text { Hydatidiform mole } \\
\text { NTD }\end{array}$ & $\begin{array}{l}\text { Twins } \\
\text { Recurrence of } \\
\text { NTD }\end{array}$ & $\frac{1}{7}$ \\
\hline 109 & & 109 \\
\hline
\end{tabular}

We did not exclude first births or women who had not had a pregnancy following an affected child as there is an observed excess of firstborn $\left(41 \cdot 3^{\circ}\right)$ affected children, comprising female meningomyeloceles $\left(46^{\circ}{ }_{0}\right)$ male encephaloceles $\left(41^{\circ}\right)$, and anencephalics $\left(42^{\circ}{ }_{0}\right)$ after correction for increased female: male ratio.

There is clearly a much higher rate of miscarriage in the pregnancy immediately before than immediately after an affected child. However, an excess abortion rate in family studies of NTDs has been well documented, and the miscarriage may well be of an affected fetus.

The evidence grows for a factor common to NTD, twinning, miscarriage, disorder of ovulation (clomiphene therapy, infertility), female births, and possibly hydatidiform mole.

Retrospective analysis of data does not dispute the hypothesis, and the lines of research suggested may provide proof. Meanwhile, a clinical application is the advisability of dilatation and curettage after miscarriage and infertility

BARBARA FIELD CHARLES KERR

Department of Preventive and Social Medicine, School of Public Health and Tropical Medicine, University of Sydney,
New South Wales

\section{Poliomyelitis immunity gaps}

SIR,-Recent publicity suggests that only half of Glasgow's children are immune to poliomyelitis. This is a misunderstanding of our report, ${ }^{1}$ which concerned children in a selected area of poverty and overcrowding. Higher 